\title{
Depression As a Strong Prediction of Suicide Risk
}

\author{
Rofingatul Mubasyiroh ${ }^{1}$, Julianty Pradono ${ }^{1}$, Enung Nurkhotimah ${ }^{1}$, Nunik Kusumawardani ${ }^{1} \&$ Sri Idaiani $^{1}$ \\ ${ }^{1}$ National Institute Health Research and Development, Indonesian Ministry of Health, Indonesia \\ Correspondence: Rofingatul Mubasyiroh, National Institute Health Research and Development, Jl. Percetakan \\ Negara 29, Jakarta 10560, Indonesia. Tel: 21-42-872-393. E-mail: rofi.litbang@gmail.com
}

\author{
Received: August 13, 2018 Accepted: October 18, 2018 Online Published: November 9, 2018 \\ doi:10.5539/gjhs.v10n12p52 URL: https://doi.org/10.5539/gjhs.v10n12p52
}

\begin{abstract}
Suicide happens throughout one's life and is a serious health problem. World Health Organization (WHO) placed suicidal problem as society health priority. Many things is related to suicide, among others mental disorders like depression, anxiety, alcohol consumption behavior, life pressure experienced, financial problem, personal relation, or so is chronic illness experienced, conflict occurred, disaster, harassment, alienation social demography characteristic. Objective research to identify the risk factor of suicidal thought in several regions in Indonesia. The study design was Cross sectional research conducted in 3 (three) districts/cities in Indonesia. Proportional illustration Sample taken conducted using stratified random sampling. Fixed variables analyzed such as the suicidal thoughts with the independent variable are gender, age, marital status, education, employment, ownership statistic, depression, anxiety. Univariate, bivariate and multivariate using the SPSS software. The result of the research showed that suicidal behavior happened more often to depressed individual, lived in the cities, anxious, productive age group, has low education level. Respondent suffered through depression 11 times more likely to have suicidal thoughts. The risk of suicidal behavior also increased 5 times to respondent in the cities. Respondent living anxiety 2 times riskier to have suicidal intent. Blue collar respondent also 2 times more risk in comparison to civil servants to have suicidal intent. Therefore it can be concluded that The influence of psychological factors is more substantial to inflict suicidal behavior, even though there is also effect of the social economy factor.
\end{abstract}

Keywords: depression, risk, suicide

\section{Introduction}

Global evidence on suicide issue has estimated about 800.000 people committed suicide every year in the world, meanwhile suicide attempt may shows higher number (WHO, 2018). Death rate from suicide in 2015 was 10.7 per 100.000 population, with ratio of 1.7 times higher in male compared to female. According to WHO in 2016, the rate in Africa was 7.4 in 100,000 population, South East Asia 13.2 per 100,000 population, Europe 15.4 per 100,000 population. In Indonesia the number is 3.4. This number is trend to be lower than Malaysia (5.5), Brunei Darussalam (4.6), Bangladesh (5.9), Myanmar (7.8) (WHO, 2018). A conclusive number of deaths from the suicide in Indonesia Number of death from suicide can be obtained from the reported case reports in the police offices (Wirasto, 2012).

Suicide may happen throughout one's life regardless of socio economy and demography diversity. . World Health Organization (WHO) placed suicidal problem as society health priority. Suicide can occur in any country in the world, whether high earnings, moderate or low earning. An individual who expressed suicidal inclination has higher risk of suicide attempt (WHO, 2014). People with high risk of suicide will need to be targeted in suicide prevention measures, as they are those who need the most for suicide prevention. A significant number people with suicidal thought experienced anxiety, depression and hopelessness and probably inadequate stress coping skill (WHO, 2018).

Several physiological determinants of suicide includes depression and current or previous anxiety (Cailhol et al., 2014; Liu et al., 2006; Inder et al., 2014; Hakim Shooshtari et al., 2016), along with other social economy and biological determinants such as alcohol consumption behavior, life pressure experienced, financial problem, personal relation as well as having chronic illness. Other several conditions that is susceptible to suicide are human or social relationship conflict, disaster, harassment, alienation (Liu et al., 2006), economic burden (Xu et al., 2015; Yin Bun Cheung et al., 2006; Hintikka et al., 1998), family member or close relatives and friend lost, and also genetic factors (Statham et al., 2013). Certain social demography gaps may contribute toward suicide related 
behavior (Nock et al., 2008; Liu et al., 2006; Inder et al., 2014; Brown et al., 2017).

Some evidence has already showed the relationship of suicide intention and mental disorders, however it is limitted to certain population settings such as hospital-based (patient) and school-based settings. In Indonesia, several studies linked to suicide intention conducted in specific population groups, such as the category of mental disorder patient (Rahmi et al., 2017; Ahmed et al., 2017), patient with methadone therapy (Istri Sadwitri Pemayun \& Ketut Sri Diniari, 2017), teenager/student category (Tresno et al., 2012; Peltzer et al., 2017; Peltzer \& Pengpid, 2007; Ratih \& Tobing, 2016); or even the suicide phenomenon due to cultural factor (Sofjan, 2011; Wirasto 2012). More specific evidence of suicide related issues and general population characteristic will be beneficial for better direction of suicide prevention by targetting specific population groups that need the most. Prevention of suicide requires specific approach for certain age groups, gender, as well as social economic status. Younger age or adolescents seem to be succeptible for suicide risk, as it is time period of having more exposure from the social environment and peers. A school-based study in Depok city in Indonesia showed proportion of mental disorders among male students grade 7 to 9 was 15\% (Kusumawardani \& Suhardi, 2011). Global School-based Health Survey in 2015 showed the prevalence of suicidal ideation in school children in Indonesia amounted to $7.3 \%$ (Mubasyiroh et al., 2017).

Gender different also important part in suicide prevention, as it has different pattern. A report of cause of death data in Indonesia showed that suicide cases was more common among males in Indonesia while the suicide intention was more common in female. The report showed proportion of suicide death among all age group was $0.12 \%$ in males and 0.05 in females from total of 25,769 deaths in 2012 (Suhardi et al., 2012b), meanwhile other analysis of population aged 15 years and above showed the proportion of suicide intention/ideation was $0.6 \%$ in males and $0.8 \%$ in females (Suhardi et al., 2012a).

Within the social economic status, previous survey had identified the proportion of suicide intention was higher among those who were not working compare $(0.9 \%$ vs $0.7 \%$ ) and under lower economic quintile (quintile 1 and 2 ) $(0.9 \%$ vs $0.6 \%)$ (Suhardi et al., 2012a). However, limited evidences yet to measure strength and prediction of relationship between psychological, social economy determinants and suicide risk from a population based survey.

This study aims to measure relationship between phsylogical, social and economy determinants towards suicide thought in three districts in Indonesia. Spesicifically, this study would like to address the research questions as follow: what was the proportion of suicide risk, depression and anxiety in different population characteristic and how was the association between suicide risk and psychological and social geography determinants.

\section{Methodology}

\subsection{Design and Sample}

This study applied a cross sectional study design in three selected districts in 2017. Data collection was completed in three districts in Indonesia, which are Bogor City (West Java), Jombang district (East Java) and Tojo Una-una district (Central Sulawesi). Bogor City and Tojo Una-una districts were selected in this study as they were two top highest proportions of mental emotional disorder (SRQ-20) during 2013 (NIHRD MoH, 2013). While Jombang is a district with low level of emotional mental disorder prevalence based on SRQ-20 (NIHRD-MOH, 2013).

This study applied stratified random sampling method to obtain selected individual sample. After selecting the districts, we randomly selected the sub-district, villages and clusters (neighborhood block) listed from the population registry office. Sampling frame used list of cluster in each sub-district and sample population was individual aged 15 years and above recorded from the population registry office in each culster. Number of sub-district, village and cluster in each district was determined proportionally according to total number of sub-district, village and cluster in each of the three districts. In Bogor City, the sample was collected from list of individual in 15 neighborhood blocks in three villages within three sub-districts, namely Central Bogor, East Bogor and Tanah Sareal. In Jombang, sample was gathered from individual list of 10 neighborhood blocks in two villages within two sub-districts, namely Diwek and Perak. In Tojo Una-una, sample was selected from individual list of 15 neighborhood blocks in three villages within three sub-districts, namely Ampana Kota District, Ampana Tete, and West Tojo. Respondents were selected randomly from the sample population within the each of selected clusters. Minimum sample was calculated using proportion estimation, with total number of selected respondent was 761 people for each district.

\subsection{Instrument}

\subsubsection{Suicide Risk}

Suicide risk was defined as having at least one condition of suicide risk such as suicide intention/ideation or 
suicide plan or attempt suicide. The instrument of suicide risk in this study included three components such as suicide ideation/intention, suicide plan and suicide attempts. The questions were "(1) During your lifetime, have you [NAME] ever intended to hurt yourself, want to suicide or wish that you [NAME] are death?"; (2) "During your lifetime, have you [NAME] ever made a plan to hurt yourself, want to suicide ?"; (3) "During your lifetime, have you [NAME] ever tried to hurt yourself, to attempt suicide?". Having suicide risk was determined by positive response ('yes') of at least one of the three questions (suicide intention or plan or attempt).

\subsubsection{Socio Demography}

Social Demographic data included: sex (male and female); age groups of 15-25 years old, 26-45 years old, 46-65 years old, and 65+ years old (Veisani et al. 2017); marital status was grouped into not married, married, ever married (divorced or died); education level was grouped into not completed elementary school, completed elementary school, completed junior high school, completed senior high school, diploma/bachelor graduate; Occupation types were Civil workers/The Indonesian National Armed Forces/Police Forces/State-owned Enterprise of Indonesia/Regionally-Owned Enterprises, private workers, Entrepreneur, Farmers, Blue-collar, Unemployed. Economic quintile was formulated using household ownership index using PCA (Principal Component Analysis) (Ariawan 2006), and it was grouped into two categories of low and high household ownership index. Geographycal population characteristics were grouped as urban and village areas based on population density, percentage of household that has agricultural related work or farmers, and access/availability of urban areas facilities (Central Bureau of Statistics, 2010).

\subsubsection{Mental Disorder}

Mental disorder in this study is defined as condition of having depression and anxiety. This study used mental health survey instrument of MINI (Mini International Neuropsychiatric Interview) Version ICD-10 that had been translated into Bahasa. Depression covered a life time experience as well as in period of two weeks prior to the survey data collection. MINI instrument pattern validation result showed that depression instrument used for general population amount to $60,68 \%$ sensitivity (NIHRD-MOH 2017).

The scale of measurement of mental disorder is nominal with the answers "yes" and "no". Categorizing mental disorder using a predetermined algorithm, not by scoring. The depression question consisted of 10 questions and positive depression was defined in condition if at least having two positive responses (yes) for question number 1 to 3 and two positive response (yes) for question number 4 to 10. (Maramis 2007). Anxiety instrument in the MINI had 68.94\% sensitivity (NIHRD-MOH 2017). The Anxiety instrument consisted of total 23 questions. Positive anxiety was defined if respondent gave positive response for question number 1 and at least had four positive responses in any of question number 2 to 23 whereas at least one positive responses for question number 2 to 5 . (Maramis 2007).

\subsection{Data Collection Procedure}

\subsubsection{Data Collecting}

Data was collected by interview using structured instrument that conducted during October to November in 2017. The interview was conducted by enumerators who had nursing education background, and had been trained by psychiatrist. Data was analyzed with suicide behavior as the fixed variable. The independent variable were gender, age, marital status, education, employment, ownership statistic, depression, anxiety.

\subsubsection{Research Ethics}

Ethical clearance of this study had been approved by Commission Health Research, National Institue of Health Research and Development, Indonesian Ministry of Health on the year 2017.

\subsection{Data Analysis}

In total there were 2,173 records had been use for the data analyses. Univariate analysis had been completed to illustrate general characteristic of respondents. Bivariate analysis using Chi-Square test had been done to measure relationship between dependent and independent variables, whereas the $p$ value was $<0.25$ based on fisher-exact for $2 \times 2$ tables and Pearson Chi-Square for more than $2 \times 2$ tables). A logistic regression analysis (unadjusted OR and adjusted OR) had been applied to assess risk magnitude of independent towards the dependent variables.

\section{Result}

This study found that of total 2,173 respondents, about $3.7 \%$ had suicide related behavior during their lifetime, $12.1 \%$ suffered depression and $6.7 \%$ experienced anxiety. Table 1 shows that number of female respondents was higher than male. Higher percentage of respondents was found in: age group of $26-45$ years (43.5\%); those who 
completed high school (28.6\%); unemployed (39.7\%); married (72.9\%); living in urban area (55.8\%); and in those who had lower economic status $(56.4 \%)$.

Table 1. Demographic characteristics of the study participants in 3 regions

\begin{tabular}{|c|c|c|}
\hline Characteristic & $\mathbf{N}$ & $\%$ \\
\hline \multicolumn{3}{|l|}{ Gender } \\
\hline Male & 884 & 40.7 \\
\hline Female & 1289 & 59.3 \\
\hline \multicolumn{3}{|l|}{ Age group } \\
\hline $15-25$ & 406 & 18.7 \\
\hline $26-45$ & 945 & 43.5 \\
\hline $46-65$ & 671 & 30.9 \\
\hline $65+$ & 151 & 6.9 \\
\hline \multicolumn{3}{|l|}{ Education } \\
\hline Diploma/Bachelor degree & 127 & 5.8 \\
\hline High School & 622 & 28.6 \\
\hline Junior High School & 487 & 22.4 \\
\hline Elementary & 528 & 24.3 \\
\hline Didn't finish Elementary school & 409 & 18.8 \\
\hline \multicolumn{3}{|l|}{ Employment } \\
\hline Civil Workers & 59 & 2.7 \\
\hline Private Worker & 151 & 6.9 \\
\hline Enterpreneur & 300 & 13.8 \\
\hline Farmer & 246 & 11.3 \\
\hline Blue Collar Worker & 554 & 25.5 \\
\hline Unemployed & 863 & 39.7 \\
\hline \multicolumn{3}{|l|}{ Marital status } \\
\hline Not Married Yet & 380 & 17.5 \\
\hline Married & 1585 & 72.9 \\
\hline Divorced & 208 & 9.6 \\
\hline \multicolumn{3}{|l|}{ Place of resident } \\
\hline Non Urban Area & 961 & 44.2 \\
\hline Urban Areas & 1212 & 55.8 \\
\hline \multicolumn{3}{|l|}{ Economy Status } \\
\hline High & 947 & 43.6 \\
\hline Low & 1226 & 56.4 \\
\hline \multicolumn{3}{|l|}{ Anxiety } \\
\hline No & 2027 & 93.3 \\
\hline Yes & 146 & 6.7 \\
\hline \multicolumn{3}{|l|}{ Depression } \\
\hline No & 1911 & 87.9 \\
\hline Yes & 262 & 12.1 \\
\hline
\end{tabular}




\begin{tabular}{lll}
\hline Suicidal behavior & & \\
\hline No & 2092 & 96.3 \\
Yes & 81 & 3.7 \\
\hline Total & 2173 & 100.0 \\
\hline
\end{tabular}

Table 2. Factor associated with Suicidal behavior of study participants

\begin{tabular}{|c|c|c|c|c|}
\hline \multirow{2}{*}{ Characteristic } & \multirow{2}{*}{$\mathbf{N}$} & \multicolumn{2}{|c|}{ Suicidal Behavior } & \multirow{2}{*}{ p-value } \\
\hline & & $\mathrm{n}$ & $\%$ & \\
\hline Gender & & & & 0653 \\
\hline Male & 884 & 31 & 3.5 & \\
\hline Female & 1289 & 50 & 3.9 & \\
\hline Age group & & & & $0.040 *$ \\
\hline $15-25$ & 406 & 13 & 3.2 & \\
\hline $26-45$ & 945 & 47 & 5.0 & \\
\hline $46-65$ & 671 & 19 & 2.8 & \\
\hline $65+$ & 151 & 2 & 1.3 & \\
\hline Education & & & & $0.016^{*}$ \\
\hline Diploma/Bachelor degree & 127 & 1 & 0.8 & \\
\hline High School & 622 & 23 & 3.7 & \\
\hline Junior High School & 487 & 15 & 3.1 & \\
\hline Elementary & 528 & 16 & 3.0 & \\
\hline Didn't finish Elementary school & 409 & 26 & 6.4 & \\
\hline Employment & & & & $0.102 *$ \\
\hline Civil Workers & 59 & 0 & 0.0 & \\
\hline Private Worker & 151 & 8 & 5.3 & \\
\hline Entrepreneur & 300 & 11 & 3.7 & \\
\hline Farmer & 246 & 14 & 5.7 & \\
\hline Blue Collar Worker & 554 & 13 & 2.3 & \\
\hline Unemployed & 863 & 35 & 4.1 & \\
\hline Marital status & & & & 0.461 \\
\hline Not Married Yet & 380 & 10 & 2.6 & \\
\hline Married & 1585 & 63 & 4.0 & \\
\hline Divorced & 208 & 8 & 3.8 & \\
\hline Place of resident & & & & $0.010^{*}$ \\
\hline Non Urban Area & 961 & 24 & 2.5 & \\
\hline Urban Areas & 1212 & 57 & 4.7 & \\
\hline Economy Status & & & & $0.235^{*}$ \\
\hline High & 947 & 41 & 4.3 & \\
\hline Low & 1226 & 40 & 3.3 & \\
\hline
\end{tabular}




\begin{tabular}{lllll}
\hline Anxiety & & & & $0.000^{*}$ \\
\hline No & 2027 & 58 & 2.9 & 15.8 \\
Yes & 146 & 23 & $0.000^{*}$ \\
\hline Depression & & & & 1.7 \\
\hline No & 1911 & 33 & 18.3 \\
Yes & 262 & 48 & \\
\hline
\end{tabular}

* significance different based on Chi-Square test with $\mathrm{p}$ value $<0.25$.

This study found that anxiety, depression, place of resident, level of education and age group has a significant relationship with respondent's suicide risk. The suicide risk was more common among those suffered depression (18.3\%), experienced anxiety (15.8\%), living in urban areas $(4.7 \%)$, education level not graduated from Elementary school (6.4\%) and the age group 26-45 years old (5.0\%) (Table 2). All the variables that had significant relationship (Chi-Square test showed $p$ value of $<0.25$ ), excluded gender and marital status, had been included in the logistic regression.

As it can be seen on Table 3, respondent who suffered depression in his/her lifetime had about 11 times more risk to have suicidal behavior. Suicide risk also increased 3 times among respondents living in urban area. Anxiety lead to two times higher risk to have suicide intention.. Respondent with blue collar work also had twice more risk to have suicide intention in comparison to respondents that work as a civil worker.

Table 3. Multivariate binary logistic regression of suicide risk of study participants

\begin{tabular}{|c|c|c|c|c|c|c|}
\hline & \multicolumn{3}{|c|}{ Unadjusted OR } & \multicolumn{3}{|c|}{ Adjusted OR } \\
\hline & OR & 95.0\% C.I. & Sig. & OR & 95.0\% C.I. & Sig. \\
\hline \multicolumn{7}{|l|}{ age group } \\
\hline $15-25$ & 1 & & & & & \\
\hline $26-45$ & 2.46 & $(0.55-11.05)$ & 0.239 & 3.71 & $(0.76-17.99)$ & 0.104 \\
\hline $46-65$ & 3.90 & $(0.94-16.22)$ & 0.061 & 4.61 & $(1.05-20.24)$ & 0.043 \\
\hline $65+$ & 2.17 & $(0.50-9.42)$ & 0.301 & 1.58 & $(0.35-7.13)$ & 0.552 \\
\hline \multicolumn{7}{|l|}{ education } \\
\hline Diploma/Bachelor degree & 1 & & & & & \\
\hline High School & 0.12 & $(0.02-0.87)$ & 0.036 & 0.15 & $(0.02-1.23)$ & 0.077 \\
\hline Junior High School & 0.57 & $(0.32-1.01)$ & 0.052 & 0.48 & $(0.24-0.98)$ & 0.044 \\
\hline Elementary & 0.47 & $(0.24-0.90)$ & 0.022 & 0.44 & $(0.20-0.94)$ & 0.035 \\
\hline Didn’t finish Elementary school & 0.46 & $(0.24-0.87)$ & 0.017 & 0.51 & $(0.25-1.03)$ & 0.060 \\
\hline \multicolumn{7}{|l|}{ Employment } \\
\hline Civil Workers & 1 & & 0.269 & & & \\
\hline Private Worker & 0.00 & $(0.00-)$ & 0.997 & 0.00 & $(0.00-)$ & 0.997 \\
\hline Enterpreneur & 1.32 & $(0.60-2.91)$ & 0.486 & 1.58 & $(0.66-3.79)$ & 0.304 \\
\hline Farmer & 0.90 & $(0.45-1.80)$ & 0.766 & 0.86 & $(0.40-1.85)$ & 0.706 \\
\hline Blue Collar Worker & 1.43 & $(0.76-2.70)$ & 0.273 & 2.23 & $(0.94-5.30)$ & 0.068 \\
\hline Unemployed & 0.57 & $(0.30-1.08)$ & 0.086 & 0.76 & $(0.38-1.51)$ & 0.433 \\
\hline \multicolumn{7}{|l|}{ Place of resident } \\
\hline Non Urban Area & 1 & & & & & \\
\hline Urban Areas & 1.93 & $(1.19-3.13)$ & 0.008 & 2.99 & $(1.54-5.79)$ & 0.001 \\
\hline
\end{tabular}




\begin{tabular}{lllllll}
\hline Economy Status & & & & & \\
\hline High & 1 & & & & & \\
Low & 0.75 & $(0.48-1.16)$ & 0.194 & 0.78 & $(0.46-1.33)$ & 0.362 \\
\hline Anxiety & & & & & & \\
\hline No & 1 & & & & & \\
Yes & 6.35 & $(3.79-10.64)$ & 0.000 & 1.90 & $(0.99-3.66)$ & 0.054 \\
\hline Depression & 1 & & & & & \\
\hline No & 1 & & & & & \\
Yes & 12.76 & $(8.02-20.33)$ & 0.000 & 10.74 & $(6.26-18.42)$ & 0.000 \\
\hline
\end{tabular}

\section{Discussion}

This study illustrated the suicide risk proportion had significantly different according to anxiety, depression, place of resident, education level and age group. Suicide risk was higher to the respondent group that suffered through depression (18.3\%). Several other studies in different settings showed similar results (22\%) (Mohammadi et al., 2005). while other study in China showed slightly higher risk (8\%) (Xu et al., 2015). Other studies in different countries also described higher risk of suicide among those who had anxiety (5.8-20\%)(Mohammadi et al. 2005; Jitender Sareen, 2005).

Suicidal behavior happened most on the 26-45 years old age group. This age group is period of economically productive age group. This result corresponds to a research in several cities in Iran (Veisani et al., 2017; Mohammadi et al. 2005). This point is different from a research in China showing no suicidal behavior prevalence contrast on any age group (Xu et al. 2015). Suicidal intention in this study considerably higher on the 26-45 years old age group (5\%). This pattern is almost similar to the global finding which discover on the younger age group 15 to 44 years old (55\%) and $45 \%$ aged older than 45 years old. Although, adolescents suicide continue to increase in many countries (News et al., 2017). Different age groups such as child and adolescents, adult and elderly may related to sensivity or coping stress ability due to psychological growth that influenced by many factors alike family bounding, social and economy environment, cultural and religous believe, and other specific individual characteristic. During child and adolescents time period, the psychological growth may related to family bounding, peer pressure and environmental-social exposure. Among adulthood period, the stressors most likely related to economic and human relationship factors. Meanwhile, psychological determinant may associated to chronic illness, lost of partners or close friends, disability or other long term conflict condition.

Suicide risk was more common among those who had lower education background, which also was found in other studies (Hakim Shooshtari et al., 2016; Xu et al., 2015), however different result was found a study in Iran and Hong Kong (Veisani et al., 2017; Liu et al., 2006; Mohammadi et al., 2005). In term of geographical aspect, respondent who live in urban area showed higher risk of having suicide risk. Similar finding also found from a study in Iran. (Mohammadi et al., 2005), however a study in Germany showed different findings (Helbich et al., 2017). Education has been known as the crucial aspect in enable individual to cope stressors, however lower education not necessaryly reffers to lower stress coping, as it may confound with other social, cultural, economy and psychological determinants. Urban living enviroment is commonly one of the stressors in term of economic gaps, population density as well as consumptive lifestyle where people becoming in high risk of becoming economically demanding and has less social or family bounding.

One of the key findings in this study was a stronger relationship of depression and suicide risk. Suicide risk may related to other physiologic determinants such as impulse-control disorders, that commonly occurred in developing countries (Nock et al., 2008). This study found very high risk of suicide related behavior among those who had depression $(\mathrm{OR}=11)$. A study in Malaysia showed slightly higher OR for suicide intention but higher OR for suicide plan (19.2) and suicide attempt (25.7) (Maniam et al., 2014). Results from the Malaysia study showed higher OR compare to studies in Iran ( $\mathrm{OR}=7-8)$ and America (Veisani et al., 2017; Sareen et al., 2005). Meanwhile study in Hong Kong showed lower risk of suicide intention among those with depression episode (OR= 8 for suicide intention and $\mathrm{OR}=3$ for suicide attempt) (Liu et al., 2006). Depression is common mental disorders that may occurs in related to other diseases among younger age groups such as children and adolescents as well as adult and elderly. World Health Organization stated that unipolar depression was in third ranking as underlying cause of illness in the year 2004 and it was estimated to be the first rank in the year 2030 (World Federation For Mental 
Health (WFMH), 2012).

Respondent who experienced anxiety had two times of greater risk to have suicida intention. and similar pattern was showed in other studies(OR=1.8-4.8) (Nock et al., 2008; Maniam et al., 2014), in Iran, Hongkong, and Australia (Veisani et al., 2017; Liu et al., 2006; Batterham et al., 2013; Kanwar et al., 2013; Sareen et al., 2005). Depression and anxiety cases are most likely to think suicide related behavior (Kanwar et al., 2013).

Evidence on suicide and geographical area in Indonesia is still limited. This study described that those who live in urban area had three times greater of having suicide risk. Oppositely, a study in Australia showed the suicide risk was higher among those living in rural area (Inder et al., 2014). Urban area is commonly representing different characteristic with rural areas, in which urban area is most likely having higher access of technology, economic growth, more industrial related work and high population density. Urban situation may lead to higher economic demand and consumption for daily living as well higher economic gap. Social structure analysis indicated that urban live was usually related to certain characters such as economy competition, work specialization, superiority achievement and social activity. Personal Identity disorder related to psychological reason can happen as a result of horn sound, phone, light reflection, stranger's view and behavior, or newspaper writing (Harahap, 2013).

This study emphasized that respondent working as a blue collar worker had two time greater risk of suicide intention compare to those who work as civil servant. Meta analysis result in thirty four studies, attained that many suicidal risk found in worker with a basic profession (such as worker and cleaner) in the working age population $(\mathrm{RR}=1.84,95 \% \mathrm{CI} 1.46-2.33)$, followed by machine operator and deck crew $(\mathrm{RR}=1.78,95 \% \mathrm{CI} 1.22-2.60)$ also farming worker ( $\mathrm{RR}=1.64,95 \% \mathrm{CI} 1.19-2.28)$. This meta analyze concluded that the low skilled work had higher suicidal risk than the highly skilled group (Batterham et al., 2013) this result also can be an input to the research need for the low skilled level population. Other studies found that psychosocial working and work stressors gained suicide risk (Schneider et al., 2011; Ozanne-Smith \& Routley, 2010; Rosta \& Aasland, 2013), while other study also found that bullying at work was independently related to serious suicidal ideation(Sterud et al., 2008).

Risk factor of suicidal behavior varied greatly, starting from genetic risk, biological susceptibility, childhood trauma, temperament and stress susceptibility (Kanwar et al., 2013). Based on this research finding, intervention to suicidal prevention can be done by individual or society/neighborhood approach. Urge government and people to cope with depression as an illness that is spreading and can affected individual, family and their surroundings. Can be done by promoting that depression can be cured (World Federation For Mental Health (WFMH), 2012). Through the program of depression and suicide or anxiety symptom prevention attempt by targeting individual by reporting if any symptom like restlessness feeling or easily offended (Batterham et al., 2013). In this matter, social support is vital to suicidal behavior prevention.

In Europe, a strategy that broaden treatment access toward suicidal prevention is proven effective in decreasing suicide stage. Besides that a multi-sectors approach also needed which is involving intervention level and other activity, like a crisis center. A strong prove shown that prevention and adequate treatment of depression, alcohol and medicine/substance abuse can decrease suicidal level. Similarly school based intervention which involve management increasing self-regard and skill development in resolving and healthy decision making has proven to decrease suicide risk in the youth circle. The available International Association support providing forum to share knowledge, give support and collaborate in suicidal prevention greatly helpful reducing suicide intent or number (News et al., 2017).

\section{Conclusion and recommendations}

Suicide risk proportion was higher in the productive age group (25-44 years old), , on low education group, living in urban area, experienced depression, and living with anxiety. Determinants of suicide risk included depression, living in urban area, living with anxiety, and work as a blue collar worker. This study concluded that psychological determinant showed stronger relationship towards suicide risk although it was also associated to social and economic determinants. Several important considerations for prevention strategies are increase life-skill capacity of young population by school-based intervention starting from very early age of toddler; creating supporting environment in school, workplaces and other community settings that enable people have healthy relationship between peers, colleagues as well as family members. Provide health services for mental health at the grass root level such as in a primary health center or clinics, specifically health care for psychological disorders such as depression and anxiety.

\section{Acknowledgements}

We are grateful to Public Health Research Center, Health Research and Development Institution, Indonesian Ministry of Health has facilitated the research fund. 


\section{Competing Interests Statement}

The authors declare that there are no competing or potential conflicts of interest.

\section{References}

Ahmed, H. U. et al. (2017). 5 Bangladesh Association of Psychiatrists. Retrieved from http://www.who-seajph.org.

Ariawan, I. (2006). Indeks Sosio-ekonomi Menggunakan Principal Component Analysis. Kesmas: National Public Health Journal, 1(2), 83-87. https://doi.org/10.21109/kesmas.v1i2.317

Batterham, P. J., Christensen, H., \& Calear, A. L. (2013). Anxiety symptoms as precursors of major depression and suicidal ideation. Depression and anxiety, 30(10), 908-916. https://doi.org/10.1002/da.22066

Brown, C. R., Hambleton, I. R., Sobers-Grannum, N., Hercules, S. M., Unwin, N., Harris, E. N., ... \& Murphy, M. M. (2017). Social determinants of depression and suicidal behaviour in the Caribbean: a systematic review. BMC public health, 17(1), 577. https://doi.org/10.1186/s12889-017-4371-z

Cailhol, L., Riedi, G., Mathur, A., Czapla, P., Charpentier, S., Genestal, M., \& Birmes, P. (2014). Faut-il hospitaliser les patients suicidants avec trouble de personnalité borderline après leur prise en charge aux urgences (étude prospective FRENCH CRISIS)?. L'Encéphale, 40(4), 289-294. https://doi.org/10.1016/j.encep.2011.02.006

Central Bureau of Statistics. (2010). Peraturan kepala badan pusat statistik nomor 37 tahun 2010: Klasifikasi perkotaan dan pedesaan di Indonesia.

Cheung, Y. B., Law, C. K., Chan, B., Liu, K. Y., \& Yip, P. S. (2006). Suicidal ideation and suicidal attempts in a population-based study of Chinese people: risk attributable to hopelessness, depression, and social factors. Journal of affective disorders, 90(2-3), 193-199. https://doi.org/10.1016/j.jad.2005.11.018

Harahap, R., \& Sos, S. (2013). Dampak urbanisasi bagi perkembangan kota di Indonesia. Jurnal Society UBB, l(1).

Helbich, M., Blüml, V., Jong, T., Plener, P. L., Kwan, M. P., \& Kapusta, N. D. (2017). Urban-rural inequalities in suicide mortality: a comparison of urbanicity indicators. International journal of health geographics, 16(1), 39. https://doi.org/10.1186/s12942-017-0112-x

Hintikka, J., Kontula, O., Saarinen, P., Tanskanen, A., Koskela, K., \& Viinamäki, H. (1998). Debt and suicidal behaviour in the Finnish general population. Acta Psychiatrica Scandinavica, 98(6), 493-496. https://doi.org/10.1111/j.1600-0447.1998.tb10125.x

Inder, K. J., Handley, T. E., Johnston, A., Weaver, N., Coleman, C., Lewin, T. J., ... \& Kelly, B. J. (2014). Determinants of suicidal ideation and suicide attempts: parallel cross-sectional analyses examining geographical location. BMC psychiatry, 14(1), 208. https://doi.org/10.1186/1471-244X-14-208

Istri Sadwitri Pemayun, C., \& Ketut Sri Diniari, N. (2017). Perilaku Bunuh Diri Pada Klien Terapi Metadon Di Ptrm Sandat Rsup Sanglah. E-Jurnal Medika, 6(5). Retrieved from http://ojs.unud.ac.id/index.php/eum

Kanwar, A., Malik, S., Prokop, L. J., Sim, L. A., Feldstein, D., Wang, Z., \& Murad, M. H. (2013). The association between anxiety disorders and suicidal behaviors: A systematic review and meta-analysis. Depression and Anxiety, 30(10), 917-929. https://doi.org/10.1002/da.22074

Kusumawardani, N. \& Suhardi, 2011. Behaviour Health Risk Among Adolescents : a School-Based Health Survey With the Focus on Smoking in Male Adolescents Aged 12-15 in Depok, West Java, Indonesia. Bidang Penelitian dan Pengembangan (Litbang) Kesehatan Nasional, Kementerian Kesehatan, (Oktober), 332-340.

Liu, K. Y., Chen, E. Y., Chan, C. L., Lee, D. T., Law, Y. W., Conwell, Y., \& Yip, P. S. (2006). Socio-economic and psychological correlates of suicidality among Hong Kong working-age adults: results from a $\begin{array}{lllll}\text { population-based } \quad \text { survey. } & \text { Psychological } & \text { Medicine, } & 36(12), & \text { 1759-1767. }\end{array}$ https://doi.org/10.1017/S0033291706009032

Maniam, T., Marhani, M., Firdaus, M., Kadir, A. B., Mazni, M. J., Azizul, A., ... \& Jasvindar, K. (2014). Risk factors for suicidal ideation, plans and attempts in Malaysia-Results of an epidemiological survey. Comprehensive psychiatry, 55, S121-S125. https://doi.org/10.1016/j.comppsych.2013.08.004

Maramis, A. (2007). Mini International Neuropsychiatric Interview Version ICD 10. Yayasan Depresi Indonesia v.2.2, 2, pp.1-20. 
Mohammadi, M. R., Ghanizadeh, A., Rahgozart, M., Noorbala, A. A., Malekafzali, H., Davidian, H., ... \& Yazdi, S. A. B. (2005). Suicidal attempt and psychiatric disorders in Iran. Suicide and Life-Threatening Behavior, 35(3), 309-316. https://doi.org/10.1521/suli.2005.35.3.309

Mubasyiroh, R., Suryaputri, I.Y. \& Tjandrarini, D.H., 2017. Determinan Gejala Mental Emosional Pelajar Mubasyiroh, R., Suryaputri, I. Y., \& Tjandrarini, D. H. (2017). Determinan Gejala Mental Emosional Pelajar SMP-SMA di Indonesia Tahun 2015. Buletin Penelitian Kesehatan, 45(2), 103-112. Retrieved from http://ejournal.litbang.kemkes.go.id/index.php/BPK/article/view/5820

News, B.W. et al. (2017). Suicide Statistics. Befrienders Worldwide News, (October).

NIHRD-MOH. (2013). Riset Kesehatan Dasar (RISKESDAS) 2013. Jakarta: NIHRD-MOH.

NIHRD-MOH. (2017). Studi Kesehatan Jiwa Pada Beberapa Daerah Di Indonesia.

Nock, M. K., Borges, G., Bromet, E. J., Alonso, J., Angermeyer, M., Beautrais, A., ... \& De Graaf, R. (2008). Cross-national prevalence and risk factors for suicidal ideation, plans and attempts. The British Journal of Psychiatry, 192(2), 98-105.

Ozanne-Smith, J., \& Routley, V. (2010). Work-related suicide. Injury Prevention, 16(Suppl 1), A272-A272. https://doi.org/10.1136/ip.2010.029215.965

Peltzer, K., \& Pengpid, S. (2007). Association of Southeast Asian Nations (ASEAN) member states. International Journal of Psychiatry in Clinical Practice, 2007-2013. Retrieved from http://www.tandfonline.com/action/journalInformation?journalCode=ijpc20

Peltzer, K., Yi, S., \& Pengpid, S. (2017). Suicidal behaviors and associated factors among university students in six countries in the Association of Southeast Asian Nations (ASEAN). Asian journal of psychiatry, 26, 32-38. https://doi.org/10.1016/j.ajp.2017.01.019

Rahmi, U. G., Yaunin, Y., \& Semiarti, R. (2017). Gambaran Angka Kejadian Tentamen Suicidum pada Penderita Gangguan Jiwa di RS Jiwa HB Saanin Periode Januari- Desember 2013. Jurnal Kesehatan Andalas, 6(2), 396-402.Retrieved from http://jurnal.fk.unand.ac.id

Ratih, A. S. W. K., \& Tobing, D. H. (2016). Konsep Diri Pada Pelaku Percobaan Bunuh Diri Pria Usia Dewasa Muda Di Bali. Jurnal Psikologi Udayana, 3(3), 430-444.

Rosta, J., \& Aasland, O. G. (2012). Changes in alcohol drinking patterns and their consequences among Norwegian doctors from 2000 to 2010: a longitudinal study based on national samples. Alcohol and alcoholism, 48(1), 99-106. https://doi.org/10.1093/alcalc/ags084

Sareen, J., Cox, B. J., Afifi, T. O., de Graaf, R., Asmundson, G. J., ten Have, M., \& Stein, M. B. (2005). Anxiety disorders and risk for suicidal ideation and suicide attempts: a population-based longitudinal study of adults. Archives of general psychiatry, 62(11), 1249-1257. https://doi.org/10.1001/archpsyc.62.11.1249

Sareen, J., Houlahan, T., Cox, B. J., \& Asmundson, G. J. (2005). Anxiety disorders associated with suicidal ideation and suicide attempts in the National Comorbidity Survey. The Journal of nervous and mental disease, 193(7), 450-454. https://doi.org/10.1097/01.nmd.0000168263.89652.6b

Schneider, B., Grebner, K., Schnabel, A., Hampel, H., Georgi, K., \& Seidler, A. (2011). Impact of employment status and work-related factors on risk of completed suicide: A case-control psychological autopsy study. Psychiatry research, 190(2-3), 265-270. https://doi.org/10.1016/j.psychres.2011.07.037

Shooshtari, M. H., Malakouti, S. K., Panaghi, L., Mohseni, S., Mansouri, N., \& Movaghar, A. R. (2016). Factors associated with suicidal attempts in Iran: a systematic review. Iranian journal of psychiatry and behavioral sciences, $10(1)$.

Sofjan, D. (2011). Social Disintegration and the Increasing Incidences of Suicide in Gunung Kidul 1. The $\begin{array}{lllll}\text { Perspectives of Local to Global. } & \text { Retrieved }\end{array}$ http://www.who.int/mental_health/prevention/suicide/suicideprevent/en/

Statham, D. J., Heath, A. C., Madden, P. A., Bucholz, K. K., Bierut, L., Dinwiddie, S. H., ... \& Martin, N. G. (1998). Suicidal behaviour: an epidemiological and genetic study. Psychological medicine, 28(4), 839-855.

Sterud, T., Hem, E., Lau, B., \& Ekeberg, Ø. (2008). Suicidal ideation and suicide attempts in a nationwide sample of operational Norwegian ambulance personnel. Journal of occupational health, 50(5), 406-414. https://doi.org/10.1539/joh.L8025

Suhardi et al. (2012a). Bunuh Diri: bahan paparan hasil analisis lanjut Registri Penyebab Kematian di 12 Kab / 
Kota.

Suhardi et al. (2012b). Laporan Analisis lanjut penyebab kematian di 12 kabupaten/kota tahun 2012, Jakarta.

Tresno, F., Ito, Y. \& Mearns, J. (2012). Self-Injurious Behavior and Suicide Attempts Among Indonesian College Students. Death Studies. https://doi.org/10.1080/07481187.2011.604464

Veisani, Y., Mohamadian, F., \& Delpisheh, A. (2017). Prevalence and comorbidity of common mental disorders and associations with suicidal ideation in the adult population. Epidemiology and health, 39, 1-6.

WHO, (2018). Suicide fact sheet. WHO. Available at: http://www.who.int/news-room/fact-sheets/detail/suicide.

Wirasto, R. T. (2012). Suicide prevention in Indonesia: providing public advocacy. Jpn Med Assoc J, 55, 98-104.

World Federation For Mental Health (WFMH). (2012). Depression: A Global Crisis. World Mental Health Day, p.32. Retrieved from http://www.who.int/mental_health/management/depression/wfmh_paper_depression_ wmhd_2012.pdf

Xu, H., Zhang, W., Wang, X., Yuan, J., Tang, X., Yin, Y., ... \& Tian, D. (2015). Prevalence and influence factors of suicidal ideation among females and males in Northwestern urban China: a population-based epidemiological study. BMC public health, 15(1), 961. https://doi.org/10.1186/s12889-015-2257-5

\section{Copyrights}

Copyright for this article is retained by the author(s), with first publication rights granted to the journal.

This is an open-access article distributed under the terms and conditions of the Creative Commons Attribution license (http://creativecommons.org/licenses/by/4.0/). 